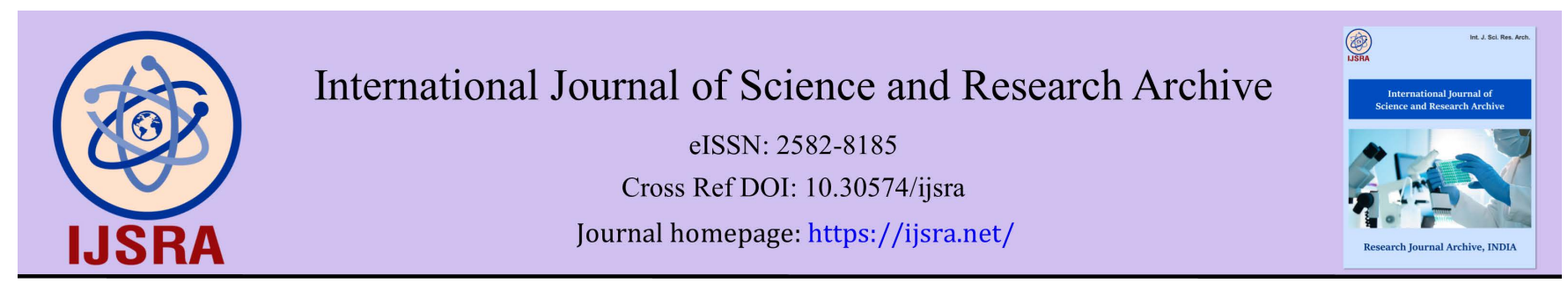

(RESEARCH ARTICLE)

Check for updates

\title{
Assessment of environmental impacts of Rabak cement factory on vegetation and soil by cement dust
} \author{
Ali Hammad Ali 4 \\ ${ }^{1}$ Public Health Department, Applied Medical Sciences, University of King Khalid, KSA. \\ ${ }^{2}$ Faculty Civil Engineering, University of University of Khartoum, Sudan. \\ ${ }^{3}$ Faculty of Science, University of Gezira, Sudan. \\ ${ }^{4}$ Al-Jafr City, Al-Rai Environmental Services Company, KSA.
}

Mazahir Elhadi Abdallah Mohammed Ali 1, ${ }^{*}$, Bashir Mohamed Elhassan 2 ${ }^{2}$, Mutaman Ali A Kehail ${ }^{3}$ and Abdelaal

International Journal of Science and Research Archive, 2021, 03(02), 053-058

Publication history: Received on 15 August 2021; revised on 20 September 2021; accepted on 22 September 2021

Article DOI: https://doi.org/10.30574/ijsra.2021.3.2.0136

\begin{abstract}
Globally, the cement industry has been identified as a factor which causes significant pollution. This study is conducted to assess environmental impacts of cement industry - Rabak Cement Factory on vegetation and soil. Standard methods were followed in collecting, preparation and examination of some plant and soil samples from the study areas. The results showed that, the mean values of soil $\mathrm{pH}$, electric conductivity and moisture contents, were $(7.58,449.38 \mu \mathrm{s} / \mathrm{cm}$, $4.56 \%)$, respectively in the exposed area, and $(7.28,343.63 \mu \mathrm{s} / \mathrm{cm}, 4.31 \%)$ in the unexposed area. There were significance differences between exposed and unexposed areas with regard to concentrations of oxides of elements $\left(\mathrm{Fe}_{2} \mathrm{O}_{3}, \mathrm{CaO}, \mathrm{MgO}, \mathrm{Mn}_{2} \mathrm{O}, \mathrm{Na}_{2} \mathrm{O}\right.$ and $\left.\mathrm{K}_{2} \mathrm{O}\right)$ in soil and in different vegetables (Radish, Jews mallow, Fennel, Rocket) in the study area. The factory management should further provide the latest technologies to reduce industrial emissions to protect the environment and population living around the factory. Further studies are needed to investigate the impacts of cement industry on environment.
\end{abstract}

Keywords: Environment; Rabak Cement Factory; Vegetation; Soil cement dust

\section{Introduction}

Cement industry caused environmental impacts at all stages of the process in the area. These include emissions of airborne pollution in the form of dust, gases, noise and vibration when operating machinery and during blasting in quarries, and damage to the countryside from quarrying [1,2]. Generally cement plants are known to be associated with exposure to quartz, cement, and dust, which can potentially contribute to Chronic Bronchitis, Silicosis and lung diseases.

The impacts of cement industry are countless and it even did not spare humans from its deteriorating impacts and have adversely impacted the health of workers. Exposure to cement pollution has been linked to a number of different health outcomes, starting from modest transient changes in the respiratory tract and impaired pulmonary function, passing to restricted activity or reduced performance, emergency room visits, hospital admissions and death $[3,4,5]$.

A great deal of attention has focused on particulate matter pollution, due to their severe health effects, especially fine particles. Particulate matter pollution in the atmosphere primarily consists of micron and sub-micron particles from anthropogenic and natural sources. The characterization of fine particles has become an important priority of

${ }^{*}$ Corresponding author: Mazahir Elhadi Abdallah Mohammed Ali

Public Health Department, Applied Medical Sciences, University of King Khalid, KSA.

Copyright (C) 2021 Author(s) retain the copyright of this article. This article is published under the terms of the Creative Commons Attribution Liscense 4.0. 
regulators, and researchers due to their potential impact on health, climate, global warming, and long- range transport [6].

Environment is a major issue, which confronts industry and business in today's world on a daily basis. Different industrial activities are degrading various environmental components like water, air, soil and vegetation [7,8]. At a local level the environmental impacts of cement production relate to 'nuisance' issues mainly through emissions of dust, noise and/or vibration as well as visual impact which, may be compounded by local quarrying operations and traffic movements associated with transport of raw materials, fuel and product.

In Rabak city residential area neighborhoods close to cement plant are constantly exposed to cement manufacturing dust and fumes. This study aims to evaluate environmental impacts of the cement industry in the Rabak city, on soil and plants.

\section{Material and methods}

\subsection{Study area}

Rabak Cement Factory is located in Rabak city and it was established in 1967 with a capacity of 350 tons per day. The factory occupies an area at a distance of $8.2 \mathrm{~km}$ from Rabak City, $300 \mathrm{~km}$ south of Khartoum, the capital of the Sudan.

\subsection{Soil and vegetation samples collection}

Soil and plant samples were collected from two agricultural areas: near the factory (about $1.5-5 \mathrm{~km}$ of the factory), to determine the concentrations of oxides of elements: ferrous oxide $\left(\mathrm{Fe}_{2} \mathrm{O}_{3}\right)$, calcium oxide $(\mathrm{CaO})$, magnesium oxide $(\mathrm{MgO})$, sodium oxide $\left(\mathrm{Na}_{2} \mathrm{O}\right)$, potassium oxide $\left(\mathrm{K}_{2} \mathrm{O}\right)$, manganese $\left(\mathrm{Mn}_{2} \mathrm{O}\right)$ in the plant samples (using Atomic Absorption Spectrophotometer), in addition to $\mathrm{pH}$ (using a digital $\mathrm{pH}$-meter), moisture (calculated from the difference between wet and oven-dry samples), ash (using oven at $450{ }^{\circ} \mathrm{C}$ ) and electrical conductivity (using conductivity meter) were determined in soil samples according to the methods described by Ryan [9].

Selected soil samples were collected using random sampling techniques from the chosen locations from depths ranged between (surface to $60 \mathrm{~cm}$ ) according to the methods described by Page [10].

\subsection{Soil Samples Preparation}

Soil samples were stored in plastic bags. Soil samples were air-dried and gently crushed and sieved through a $2 \mathrm{~mm}$ sieve and stored for chemical analysis according to the methods described by MPCA [11].

\subsection{Plant Tissue Samples Preparation}

After planting samples were collected, roots and foreign materials attached to the samples were removed and discarded. The samples were weighed and air-dried in the sun for one to two days to avoid mold formation.

\subsection{Data analysis and processing}

Statistical analysis was carried out with the Statistical Package for Social Sciences (SPSS) version 21 for windows and Microsoft Excel 7. One-way analysis of variance (ANOVA) was used to determine whether there was a significant difference in the parameters measured at various locations [12].

\section{Results and discussion}

\subsection{Soil composition in exposed and unexposed areas}

The results indicate that there was a high significant difference $(\mathrm{P}=0.05)$ respectively between exposed and unexposed areas in $\mathrm{pH}$ (7.58 and 7.28), soil electrical conductivity (449.38 and 343.63) and moisture content (4.56 and 4.31) at different depths of the soil, but there was no significance differences in ash content (4.06 and 2.65) between exposed and unexposed areas (Table, 1).

Cement dust has been shown to adversely affect the soil ecological communities. Soil surrounding cement factories, especially downward areas, exhibit elevated $\mathrm{pH}$ levels. The soil compositions usually affect vegetative growth [13]. The soil chemical properties are very important parameters in monitoring environmental pollution. 
The results showed that the soil is moderately alkaline in an exposed area, as was suggested by Page [10] who leveled moderately alkaline at the $\mathrm{pH}$ range of (7.5- 8.5). Soil $\mathrm{pH}$ is important because it influences the availability and plant uptake of micronutrients including heavy metals [14].

Conductivity showed the concentration of electrolyte in the soil. Zerrougi [1] reported that in order to detect the impact of cement dust on the upper $3 \mathrm{~cm}$ layer of soil, the electric conductivity should be measured. In other study, the level of soil EC around cement factory was found comparatively highest. This is due to the significant amount of cement dust added into the soil surface. Based on the results, level of soil conductivity was found to increase considerably under the influence of cement dust [15].

Table $1 \mathrm{pH}$ in different depths in exposed and unexposed areas

\begin{tabular}{|l|c|c|c|c|c|c|}
\hline \multicolumn{2}{|c|}{ Depths/cm } & $\mathbf{0 - 0}$ & $\mathbf{0}-\mathbf{1 0}$ & $\mathbf{1 0}-\mathbf{3 0}$ & $\mathbf{3 0}-\mathbf{6 0}$ & Mean \\
\hline \multirow{2}{*}{ Soil pH } & Exposed & 7.50 & 7.49 & 7.56 & 7.77 & 7.58 \\
\cline { 2 - 7 } & Unexposed & 7.12 & 7.28 & 7.29 & 7.43 & 7.28 \\
\hline \multirow{2}{*}{ Soil EC $(\mu \mathrm{s} / \mathrm{cm})$} & Exposed & 320.25 & 738.75 & 122.25 & 385.25 & 449.38 \\
\cline { 2 - 7 } & Unexposed & 341 & 324.25 & 284 & 425.25 & 343.63 \\
\hline \multirow{2}{*}{ Moisture content } & Exposed & 5.38 & 3.69 & 3.69 & 5.50 & 4.56 \\
\cline { 2 - 7 } & Unexposed & 4.39 & 4.08 & 3.56 & 5.19 & 4.31 \\
\hline \multirow{2}{*}{ Ash content } & Exposed & 4.31 & 4.10 & 3.87 & 3.96 & 4.06 \\
\cline { 2 - 7 } & Unexposed & 2.12 & 2.36 & 2.53 & 3.30 & 2.65 \\
\hline
\end{tabular}

The concentration (\%) of some oxides of elements $\left(\mathrm{Fe}_{2} \mathrm{O}_{3}, \mathrm{CaO}, \mathrm{MgO}, \mathrm{Mn}_{2} \mathrm{O}, \mathrm{Na}_{2} \mathrm{O}\right.$ and $\left.\mathrm{K}_{2} \mathrm{O}\right)$ at different depths around the factory (exposed area) are shown in Table $(2)$ indicated that there were significant difference $(\mathrm{P}<0.01)$ in their concentrations. The results also show the presence of these oxides even in the surface soil. The detected high mean concentration was that of $\mathrm{MgO}(72.09 \%)$ while the least mean concentration was of $\mathrm{Fe}_{2} \mathrm{O}_{3}(0.77 \%)$.

Table 2 Concentrations (\%) of some oxides of elements in different soil depths in exposed area

\begin{tabular}{|l|c|c|c|c|c|}
\hline Depths/cm & $\mathbf{0}-\mathbf{0}$ & $\mathbf{0}-\mathbf{1 0}$ & $\mathbf{1 0}-\mathbf{3 0}$ & $\mathbf{3 0}-\mathbf{6 0}$ & Mean \\
\hline $\mathrm{Fe}_{2} \mathrm{O}_{3}$ & 1.6 & 0.17 & 0.40 & 0.86 & 0.77 \\
\hline $\mathrm{CaO}$ & 76.92 & 68.86 & 66.90 & 62.43 & 68.77 \\
\hline $\mathrm{MgO}$ & 74.37 & 77.06 & 73.41 & 63.54 & 72.09 \\
\hline $\mathrm{Mn}_{2} \mathrm{O}$ & 0.20 & 0.36 & 0.11 & 0.102 & 0.193 \\
\hline $\mathrm{Na}_{2} \mathrm{O}$ & 21.21 & 16.2 & 22.75 & 42.08 & 25.56 \\
\hline $\mathrm{K}_{2} \mathrm{O}$ & 2.92 & 2.06 & 1.50 & 1.66 & 2.04 \\
\hline Total & \multicolumn{7}{|c|}{} & 28.24 \\
\hline
\end{tabular}

Concentrations of some oxides of elements found at different depths of soil samples taken from area far from the factory (unexposed area) were presented in Table (3). The result indicates that there was a high significant difference at $(\mathrm{P}<0.01)$ in concentrations of all element oxides at different depths. The mean concentration of $\mathrm{MgO}$ is higher in the exposed area (72.09\%) compared to unexposed area (59.66\%). The results also showed that the mean concentration of $\mathrm{Fe}_{2} \mathrm{O}_{3}$ was less in exposed areas $(0.77 \%)$ with comparison to unexposed area (3.83\%).

The study found that there was a slight variation in means of concentration of these oxides in the two areas. The slightly higher concentrations of oxides of elements in unexposed area may be as the result of the normal presence of these oxides of elements in that soil. The overall results indicate that all above factors had played an important role behind 
the slightly higher concentration of some oxides of element deposits in soil and vegetation in the unexposed area than the exposed area.

Table 3 Concentrations of some oxides of elements in different soil depths in unexposed area

\begin{tabular}{|l|c|c|c|c|c|}
\hline Depths/cm & $\mathbf{0}-\mathbf{0}$ & $\mathbf{0}-\mathbf{1 0}$ & $\mathbf{1 0}-\mathbf{3 0}$ & $\mathbf{3 0}-\mathbf{6 0}$ & Mean \\
\hline $\mathrm{Fe}_{2} \mathrm{O}_{3}$ & 4.35 & 4.20 & 4.61 & 2.17 & 3.83 \\
\hline $\mathrm{CaO}$ & 79.04 & 56.80 & 69.65 & 65.37 & 67.72 \\
\hline $\mathrm{Mg} \mathrm{O}$ & 37.75 & 76.50 & 60.33 & 64.06 & 59.66 \\
\hline $\mathrm{Mn}_{2} \mathrm{O}$ & 4.60 & 6.24 & 3.91 & 4.74 & 4.87 \\
\hline $\mathrm{Na}_{2} \mathrm{O}$ & 29.73 & 27.33 & 51.27 & 79.15 & 46.87 \\
\hline $\mathrm{K}_{2} \mathrm{O}$ & 4.49 & 3.21 & 2.72 & 2.46 & 3.22 \\
\hline \multicolumn{5}{|c|}{ Cal.F-value $=23.85^{* *} ; \mathrm{CV}=40.1 \% ; \mathrm{SE} \pm=8.8$} & \\
\hline
\end{tabular}

\subsection{Effect of dust exposure on plant chemistry}

The concentrations of some oxides of elements in vegetables grown in exposed areas around the factory were shown in Table (4). The results revealed that the highest mean concentration of MgO (549.08\%) was found in all vegetables, including Radish, Jews mallow, Fennel and Rocket, and the least concentration was of $\mathrm{Mn}_{2} \mathrm{O}$ (2.15\%). The statistical analysis showed that there was a highly $(\mathrm{P}=0.01)$ significant abundance of such oxides in different vegetables grown in exposed area around the factory.

The obtained results agrees with TRF [16] who found that, exposure to cement dust for a short period may not cause serious problems, however prolonged exposure can cause serious irreversible damage to plants and animals. Cement dust of sufficient quantities have been reported to dissolve leaf tissues. Seker and Ozaytekin [17] found that, the increase of $\mathrm{K}^{+}$is attributed to cement dust pollution. Similar finding reported that cement dust improved potassium content in soil and tend to remain higher than other cations.

Table 4 Concentration of some oxides of elements in different vegetables exposed to cement dust in Rabak city

\begin{tabular}{|l|c|c|c|c|c|}
\hline Elements oxide & Radish & Jews mallow & Fennel & Rocket & Mean \\
\hline $\mathrm{Fe}_{2} \mathrm{O}_{3}$ & 40.0 & 44.39 & 47.44 & 41.37 & 43.3 \\
\hline $\mathrm{CaO}$ & 594.9 & 211.80 & 139.20 & 607.52 & 388.35 \\
\hline $\mathrm{Mg} \mathrm{O}$ & 719.7 & 467.36 & 343.74 & 665.54 & 549.08 \\
\hline $\mathrm{Mn}_{2} \mathrm{O}$ & 2.04 & 1.6 & 2.36 & 2.60 & 2.15 \\
\hline $\mathrm{Na}_{2} \mathrm{O}$ & 513.40 & 134.94 & 510.37 & 269.26 & 356.99 \\
\hline $\mathrm{K}_{2} \mathrm{O}$ & 275.07 & 281.83 & 608.25 & 652.92 & 454.52 \\
\hline \multicolumn{7}{|c|}{ Cal.F- value $=7.17^{* *} ; \mathrm{CV}=56 \% ; \mathrm{SE} \pm=55.8$} \\
\end{tabular}

The mean concentration of $\mathrm{MgO}(809.45 \%)$ was found to be the highest in all vegetables among other oxides of the elements followed by $\mathrm{Na}_{2} \mathrm{O}$ (356.99\%), $\mathrm{K}_{2} \mathrm{O}$ (501.03\%) $\mathrm{CaO}(245.41 \%), \mathrm{Fe}_{2} \mathrm{O}_{3}(37.26 \%)$ and the least was $\mathrm{Mn}_{2} \mathrm{O}(4.95 \%)$. Generally, the results obtained from the exposed and unexposed areas indicate that the concentration of all oxides of elements in exposed areas was significantly higher than that obtained from the unexposed area $(\mathrm{p}<0.05)$. However, due to deposition of cement dust on the soil near the cement plants, this caused a change in soil pH to the alkaline side. Cement dust contains $\mathrm{CaCO}_{3}$, resulting in alkalinity when it comes in contact with soil $[18,19]$.

The overall results indicate that there was a significant deposit of oxides of elements in vegetables grown in exposed area due to cement dust from the factory. The results also indicate that oxides of elements in vegetables grown in an unexposed area might highlight the idea that, these elements' oxides were naturally present in the unexposed area. 
Table 5 Concentration of some oxides of elements in different vegetables unexposed to cement dust in Rabak city

\begin{tabular}{|l|c|c|c|c|c|}
\hline Elements oxides & Radish & Jews mallow & Fennel & Rocket & Mean \\
\hline $\mathrm{Fe}_{2} \mathrm{O}_{3}$ & 28.72 & 33.95 & 43.25 & 43.13 & 37.26 \\
\hline $\mathrm{CaO}$ & 11.68 & 111.68 & 130.34 & 627.92 & 245.41 \\
\hline $\mathrm{Mg} \mathrm{O}$ & 1492.98 & 692.46 & 177.09 & 876.24 & 809.42 \\
\hline $\mathrm{Mn}_{2} \mathrm{O}$ & .039 & 3.17 & 1.19 & 14.49 & 4.95 \\
\hline $\mathrm{Na}_{2} \mathrm{O}$ & 1612.02 & 165.80 & 503.20 & 853.51 & 783.63 \\
\hline $\mathrm{K}_{2} \mathrm{O}$ & 281.77 & 645.28 & 347.02 & 730.03 & 501.03 \\
\hline $\mathrm{Total}$ & \multicolumn{5}{|l}{ Cal.F- value $=3.85^{*} ; \mathrm{CV}=91 \% ; \mathrm{SE}= \pm 62.30$} \\
\hline
\end{tabular}

\section{Conclusion}

- There was a high significant difference between exposed and unexposed areas in pH, soil electrical conductivity and moisture content at different depths of the soil.

- There was no significance difference in ash content between exposed and unexposed areas in soil.

- There was a significant difference in concentrations of all element oxides at different depths of soil.

- There was a significant deposit of oxides of elements in vegetables grown in exposed and unexposed area.

\section{Compliance with ethical standards}

\section{Acknowledgments}

Thanks are due for Dr. Bashir Mohamed Elhassan, Dr. Amir Ali Bashir and Dr. Zainab Osman Saaeed, who providing the required technical support, in addition to the staff of the Lab. Of Environment and Natural Resources Research Institute and Natural center for Research.

\section{Disclosure of conflict of interest}

The authors (Mazahir, Bashir, Mutaman and Abdelaal) declare no conflicts of interest regarding the publication of this paper.

\section{Statement of ethical approval}

The present research work does not contain any studies performed on animals/humans subjects by any of the authors.

\section{References}

[1] Zerrouqi ZM, Sbaa M, Oujidi M, Elkharmouz S. Assessment of cement's dust impact on the soil using principal component analysis and GIS. Int J Environ Sci Tec. 2008; 5: 125-134.

[2] Nasr D, Massoud MA, Khoury R, Kabakian V. Environmental impacts of reconstruction activities, A case of. Lebanon. Int J Environ Res, 2009, 3(2), 301-308.

[3] Schuhmacher M, Domingo JL, Garreta J. Pollutants emitted by a cement plant: health risks for the population living in the neighborhood. Environmental Research. 2004; 9(52): 198-206.

[4] Aydin S, Croteau G, Sahin I, Citil C. Nitrite and Paraoxonase/Arylesterase. Concentrations in Cement Plant Workers. Journal of Medical Biochemistry. 2010; 29(2): 78-83.

[5] Zeleke Z, Moen B, Bratveit M. Cement dust exposure and acute lung function: A cross shift study. BMC Pulmonary Medicine. 2010; 10(1): 19.

[6] EIPPC, European Integrated Pollution Prevention and Control. Bureau, Reference Document on Best Available Techniques in the Cement and Lime Manufacturing Industries, Seville. 2001. 
[7] Murugesan M, Sivakumar A, Jayanthi N, Manonmani K. Effect of cement dust pollution o physiological and biochemical activities of certain plants. Pollution Research. 2004; 23(2): 375-378.

[8] Kumar V, Ramachandran TV, Prasad R. Natural radioactivity in Indian building materials and byproducts. J RadioanalNucl Chem. 2011; 266:936.

[9] Ryan J, George E, Abdul R. Soil and Plant Analysis Laboratory Manual. Second Edition. Jointly published by the International Center for Agricultural Research in the Dry Areas (ICARDA) and the National Agricultural Research Center (NARC). Available from ICARDA, Aleppo, Syria. x+172. 2001.

[10] Page AL. Methods of soil analysis. Madison, United States of America. 1986.

[11] MPCA, Minnesota Pollution Control Agency. Soil Sample Collection and Analysis Procedures. 2008.

[12] Lyman OTT. An introduction to statistical methods and data analysis, An Imprinl of Wednworth, Inc. 1992.

[13] Ade-Ademilua OE, Umebese CE. The growth of Phaseolus vulgaris L. cv. Ife Brown (Leguminosae) in a cement site rich in heavy metals. Pak J Biol Sci. 2007; 10(1):182-185.

[14] Kirkham MB. Cadmium in plants on polluted soils: Effects of soil factors, hyper accumulation and amendments. Geoderma. 2006; 137(1-2): 19-32.

[15] Lamare ER, Singh OP. Effect of cement dust on soil physico-chemical properties around cement plants in Jaintia Hills, Meghalaya. Environmental Engineering Research. 2020; 25(3): 409-417.

[16] TRF, Tropical Rain Forest. Air pollution effects: Effects on forests, trees and plants. 2008.

[17] Seker C, Ozaytekin HH. Effect of portland cement on soil mechanical properties and seedling emergence of wheat in a silty loam soil. In: International Conference on Sustainability. 2002; 274-281.

[18] Swiercz A. Suitability of fine bark to evaluate pollution caused by cement-lime dust. J For Sci. 2006;52: 93-98.

[19] Oludoye 00, Ogunyebi LA. Nutrients assessment of tropical soils around a mega cement factory in Southwest Nigeria. J Ecol Eng. 2017;18:21-28. 